\title{
TITLE:
}

\section{Variation in the safety of induced pluripotent stem cell lines( Abstract_要旨)}

$\operatorname{AUTHOR}(\mathrm{S})$ :

Miura, Kyoko

\section{CITATION:}

Miura, Kyoko. Variation in the safety of induced pluripotent stem cell lines. 京都大学, 2010, 博士(医学)

\section{ISSUE DATE:}

2010-03-23

URL:

http://hdl.handle.net/2433/120546

RIGHT: 


\begin{tabular}{|l|l|c|l|}
\hline 京都大学 & 博士 (医学) & 氏 名 & 三浦 恭子 \\
\hline 論文題目 & $\begin{array}{l}\text { Variation in the safety of induced pluripotent stem cell lines. } \\
\text { (人工多能性幹細胞株の安全性の多様性) }\end{array}$ \\
\hline
\end{tabular}

\section{(論文内容の要旨)}

近年、体細胞に数種の遺伝子を導入することにより、ES 細胞様の人工多能性幹 （induced pluripotent stem：iPS）細胞が作成された。iPS 細胞を移植治療へと応 用することにより、ES 細胞の抱える問題点（免疫拒絶反応や倫理的な問題）を回 避することができると考えられる。しかし、iPS 細胞は遺伝子を導入することによ り人工的に初期化された細胞であることから、その安全性については厳密な評価 が必要とされる。現在、iPS 細胞は様々な体細胞から様々な方法により樹立されて いるが、どのように樹立した iPS 細胞が最も分化能が高く安全であるかは、いま だ不明である。以上の背景のもと、本論文では、神経系細胞への分化誘導をモデ ルとして、(1)体細胞の由来の違い、(2) $\mathrm{c}-\mathrm{Myc}$ 導入の有無、(3)樹立時の薬剂而性レポ 一ターによる選択の有無が、マウス iPS 細胞の分化能と移植後の安全性に与える 影響を検討した。

\section{1.iPS 細胞の分化誘導への応答性は由来となった体細胞の種類により異なる}

マウス iPS 細胞 36 株から神経幹/前駆細胞を含むニューロスフェア (NS) の分 化誘導を行ったところ、ほぼすべての iPS 細胞株は NS に分化可能であった。 より詳細に分化誘導への応答性を比較するため、分化誘導後の NS 中に残存す る未分化細胞をフローサイトメトリーによって検出したところ、NS 中の未分化 細胞の残存率は、iPS 細胞の由来となった体細胞の種類により大きく異なるこ とが明らかとなった。胎児線維芽細胞由来 iPS (MEF-iPS) 細胞株は ES 細胞と同 等の分化誘導への応答性を示し、分化誘導後の NS 中に未分化細胞はほとんど 残存していなかった。一方、成体尾線維芽細胞由来の iPS（TTF-iPS）細胞株は 有意に分化抵抗性を示し、分化誘導後の NS 中には多くの未分化細胞が残存し ていた。成体肝細胞（Hep）由来 iPS 細胞株の分化誘導への応答性は、MEF-iPS 細胞株と TTF-iPS 細胞株の中間であった。意外なことに、c-Myc の導入の有無 と樹立時の薬剤レポーターによる選択の有無は、iPS 細胞の分化誘導への応答 性に影響を与えなかった。

2.iPS 細胞由来ニューロスフェアの移植後の安全性は由来となった体細胞の種類 により異なる

次に安全性の評価として、各 iPS 細胞株由来 NS を免疫不全（NOD/Scid）マウスの 脳線条体へ移植し、経過観察を行った。結果、分化誘導への応答性と同様に、iPS 細胞由来 NS の移植後の安全性も、元の体細胞の由来の種類によって大きく異なる ことが判明した TTF-iPS 細胞株由来 NS を移植したマウス群においては、多くが 短期間のうちにテラトーマ形成により衰弱もしくは死亡した。一方、MEF-iPS 細胞 株由来 NS 移植群においては、テラトーマ形成は ES 細胞株由来 NS 移植群と同等に 低頻度且つ軽微であった。Stm-iPS 細胞株由来 NS 移植群においては、テラトーマ 形成は観察されなかった。Hep-iPS 細胞株由来 NS 移植群は、MEF-iPS 細胞株由来 NS 移植群と TTF-iPS 細胞株由来 NS 移植群の中間レベルの腫瘍形成を示した。c-Myc 導入の有無と樹立時の選択の有無は、移植後の安全性に影響を与えなかった。 以上の結果から、iPS 細胞由来分化細胞の移植治療の安全性を確立するためには、
iPS 細胞樹立時に由来の体細胞を慎重に選択寸ることが重要であることが明らか となった。今後、他の分化誘導法の検討、ヒト iPS 細胞での検討、また、安全な 由来の体細胞のさらなる探索を、慎重に進めていく必要がある。

\section{(論文審査の結果の要旨)}

近年、体細胞に数種の遺伝子を導入することにより、 $\mathrm{ES}$ 細胞様の人工多能性幹 （induced pluripotent stem: iPS）細胞が作成された。iPS細胞を移植治療へと応用するこ とにより、ES細胞の抱える問題点（免疫拒絶反応や倫理的な問題）を回避できると考え られる。しかし、iPS細胞は遺伝子導入によって人工的に初期化された細胞であることか ら、その安全性については厳格な評価が必要とされる。現在、iPS細胞は様々な体細胞か ら様々な方法により樹立されているが、どのように樹立したiPS細胞が最も分化能力が高 く安全であるかは、いまだ不明である。そこで本研究では、神経系細胞への分化誘導を一 デルとして、(1)体細胞の由来の違い、(2)c-Myc導入の有無、(3)樹立時の薬剤而性レポータ 一による選択の有無が、iPS細胞の分化能と移植後の安全性に与える影響を検討した。マ ウスiPS細胞36株からニューロスフェアの分化誘導を行い、NOD/Scidマウス脳線条体一 と移植することにより安全性評価を行ったところ、iPS細胞の分化能と安全性は、体細胞 の由来によって大きく異なるといらことが明らかとなった。一方、c-Mycの導入の有無と 樹立時の選択の有無は、分化能と移植後の安全性に影響を与えなかった。

以上の研究は、樹立時の由来となる体細胞の選択が、iPS細胞の安全性の確立のため に非常に重要であるということを世界で初めて解明したものであり、真に安全なiPS細胞 の樹立に向けて大きな貢献を果たした。したがって、本論文は博士（医学）の学位論文と して価值あるものとみとめる。

なお、本学位授与申請者は、平成 21 年 12 月 22 日実施の論文内容とそれに関連した試 問を受け、合格と認められたものである。 